\title{
PREPARATION OF LAND USE ZONING MAPS OF CHAUMALA VDC, KAILALI
}

\author{
Devraj Chalise $^{1 *}$, Abhasha Joshi ${ }^{2}$, Bikesh Twanabasu ${ }^{3}$, Nabin Rawal ${ }^{1}$ and Saroj Amgai ${ }^{4}$ \\ ${ }^{1}$ Nepal Agricultural Research Council, Nepal \\ ${ }^{2}$ University of Münster, Germany \\ ${ }^{3}$ Universitat Jaume I Casetellon de ta Plana, Spain \\ ${ }^{4}$ University of Technology Sydney, Australia \\ *Corresponding author: chalisedevraj@gmail.com
}

\begin{abstract}
To characterize soils of different land uses and to prepare land use zoning maps, a field survey was conducted in August, 2014 in Chaumala VDC, Kailali. Main objective was to prepare scientific land resource inventory at VDC level to delineate land use based on land types, associated soils and land capability classes to formulate sustainable land use planning. The maximum area is allocated in forest zone (66.62\%) followed by agriculture zone $(20.83 \%)$. Area allocated as public use is $9.48 \%$, for residential is $2.91 \%$, and for commercial is $0.15 \%$ whereas industrial area covers the minimum $(0.01 \%)$. Detailed land resource inventory is utmost for better land use planning and formulating best land use policies.
\end{abstract}

Keywords: inventory; land resource; land system; land use; zoning map

\section{Introduction}

Generally a detailed study of land use pattern, land system, land type, land capability, geology and natural hazards of the study is required to formulate a classification scheme for land use zoning. Land use zoning is assessed based on the suitability of sustainable use for a specific purpose. Land use zoning differs from land capability classification in a sense that land capability is general classification of land based on arability and productivity of soil without degradation or off site effects for farming. Zoning plans, which consist of textual documents, alphanumerical tables, and graphical maps have been employed in the management of appropriate land uses in both urban and rural areas for quite some time (Keeble, 1969; Chapin and Kaiser, 1979; Last, 1995; van der Vlist, 1998). Zone planning, a process to produce zoning plans, involves many fields, including design art, engineering, and the sciences (Blunden, 1971; Catanese, 1972; Sol et al., 1995; Alexander, 1998). Land use planning is required to best utilize the limited land resources based on inherent qualities. This will address the issues of food security, land degradation, forest and wild life protection, hazard mitigation, and physical development. Except sporadic attempts for the urban areas (GoN, 2012), Nepal has not practiced land-use planning for the country as a whole, although attempts were made for balanced use of country's existing natural resources in the past through different polices and national planning efforts. Land use planning is the systematic assessment of the land and water potential, alternatives for land use and economic and social conditions in order to select and adopt the land use options (FAO, 1993). In contrary, land use zoning is the suitability classification of land for various land use purposes. The suitability classes are rated from the most suitable to the least. Each suitability class is therefore designated a zone with suitability ratings. Based on the suitability of land for various land use classes, land use zones are classified into six broad categories with associated ratings. The zoning is done for agriculture, residential, commercial, industrial, forest and public utility zones. Main objective of the study is to prepare a scientific and comprehensive land resource inventory at VDC level and assess and delineate land use based on land types, associated soils and land capability classes with the main to formulate a sound and sustainable land use planning. The present study aims to fulfil the following major objectives:

- To classify agricultural lands for the purpose of identifying most suitable and lucrative crop production and classify land for non-agricultural purpose based on land types and associated land characteristics,

- To prepare land use zoning maps of the selected VDCs at 1:10,000 scale portraying different zones and sub-zones as per the Governmental Land Use policy, 
- To prepare appropriate GIS database on present land use zoning of the selected VDCs; and

- To prepare reports on conceptual basis and methodology of land use zoning and models of GIS database

\section{Materials and Methods}

\section{Study Area}

The study VDC lies in northern part of Kailali district along East-West Highway as shown in the Fig. 1.

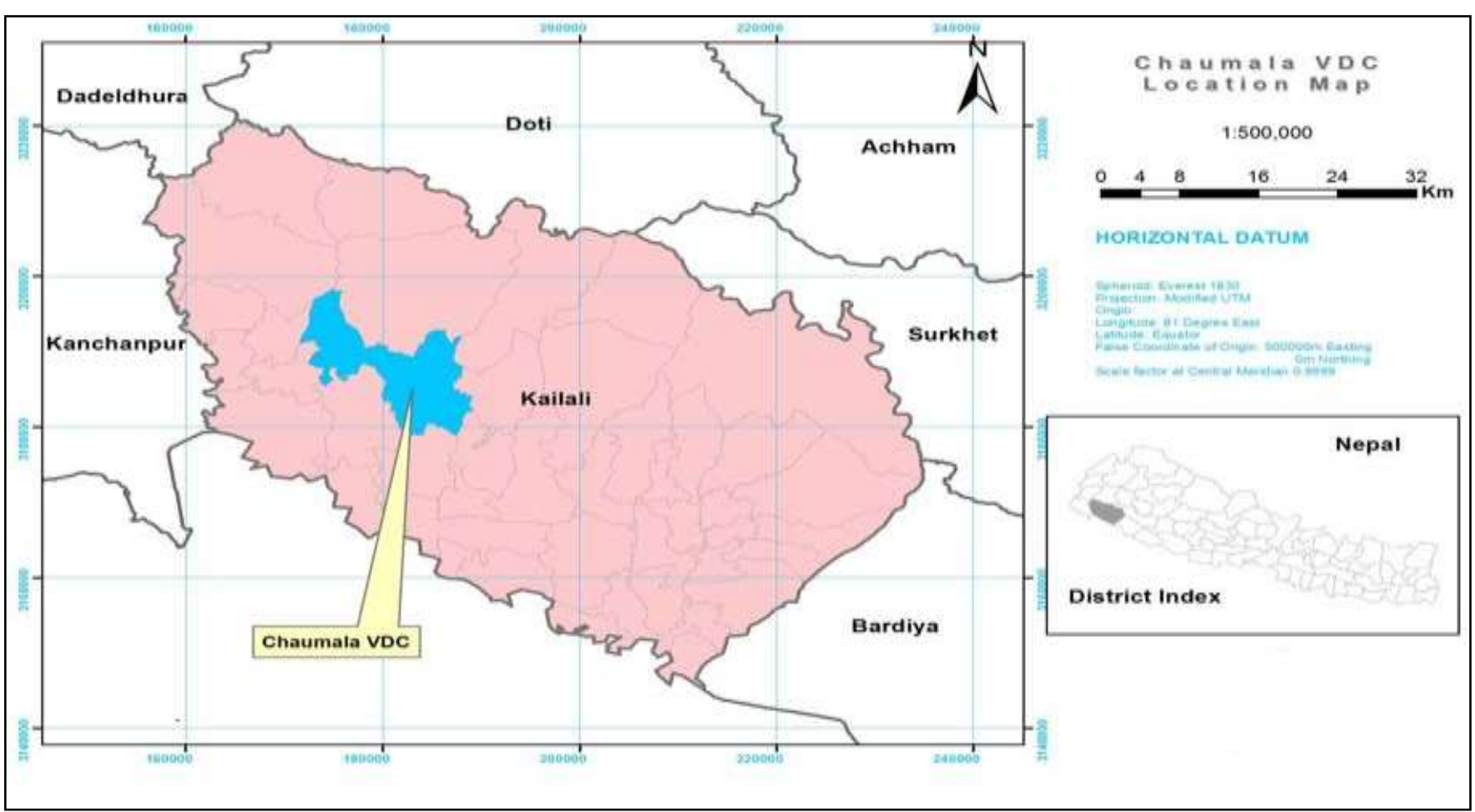

Fig.1: Location of study VDC

\section{Conceptual Basis of Land Use Zoning}

\section{Land Use Zoning, Principles and Criteria}

Considering the importance of land use zoning, National Land Use Project, Ministry of Land Reform and Management has underlaid the following concepts for the land use zoning:

- Classification of land into agricultural area, residential area, commercial area, industrial area, public service area and other uses,

- Identifying areas of potential residential, commercial, industrial and public utility keeping balanced environment.

- Classifying agricultural land into comparatively advantageous sub-areas on the basis quality of land, land capability, irrigation facilities to increase productivity.

- $\quad$ Proper conservation of natural resources including forest, shrub, rivers, rivulets and swampy land etc.

Multi-Criteria Analysis (MCA) using spatial data pertaining to topography, soil, moisture, drainage, and climate and socio-economic and infrastructures was done.

\section{Land Use Zoning and Their Descriptions}

For the purpose of the land use zones, six land use zones were considered as per NLUP's specification. Zone 1 describes the area preferably suitable for cereal/food crop production area, cash crops, animal husbandry, cash crop, horticulture, animal husbandry, fish farming, agro-forestry. Zone 2 is appropriate location for residential purpose, both existing and potential. Zone 3 is commercial zone, prescribed location for government institutions and service area as well as business areas. Zone 4 is for industrial use. Zone 5 is set aside for existing forests as well potential forest areas including barren lands, wet lands etc. Zone 6 is public utility zone.

\section{Methodology}

Data

There are many different sources of information on existing land use and land cover and on changes that are occurring. Local planning agencies make use of detailed information generated during ground surveys involving enumeration and observation. Interpretation of large-scale aerial photographs also has been used widely. In some cases, supplementary information is inferred on the basis of utility hookups, building permits, and similar information. Major problems are present in the application and interpretation of the existing data. These include changes in definitions of categories and data collection methods by source agencies, incomplete data coverage, varying data age, and employment of incompatible classification systems. In addition, it is nearly impossible to aggregate the available data because of the differing classification systems used (Anderson, 1971). 
The primary data source used for the land use classification in this project is high resolution satellite image $(0.5 \mathrm{~m}$ spatial resolution, Mx). Various other vector, raster and imagery data sets were used as ancillary data, which enhanced interpretation and classification of land use classes.

Besides, the present land use, land capability and soil maps were prepared as part of the present study, which are also the major data sources for the preparation of VDC level Land Use zones.

\section{Methods}

A rule based Multi Criteria Evaluation (MCE)/Multi Criteria Approach (MCA) was developed for optimum use of land resources of the VDCs under the following broad land use zones: Agricultural area, Residential area, Commercial area, Industrial area, Forest area, Public service area and other category.

The input for the application is a number of maps of each Village Development Committee (so-called 'criteria' or 'effects'), and a criteria tree that contains the way criteria are grouped, standardized and weighed. The output of MCA based on weight/rating consists of composite index maps that indicate the extent to which criteria for different classes of land capability or suitability for land use zoning for a location are met. For example, on the basis of maximum productivity and fertility, agricultural areas have been divided into sub areas of cereal/food crops area; cash crops area; vegetable production area, fruit orchard, area used for animal husbandry and grassland/grazing lands, fish farming area and agro- forestry. The MCE/MCA Criteria was developed as per guidance by the environmental friendly perspective and as far as possible. Special care was given to maintain and preserve maximum forest areas, protection of food crop producing areas, conserving eco- system and biodiversity and providing unproductive areas for settlement.

\section{General Approach and Methodology Framework}

Land use zoning class and suitability ratings are evaluated based on aforementioned criteria and the land use unit is designated with appropriate land use zone class along with its suitability value. The approach for classification and designation of land use zones is presented in the Fig. 2.

Table 1 shows the hierarchical use zones and sub-zones were followed while zoning the land use of the study area.

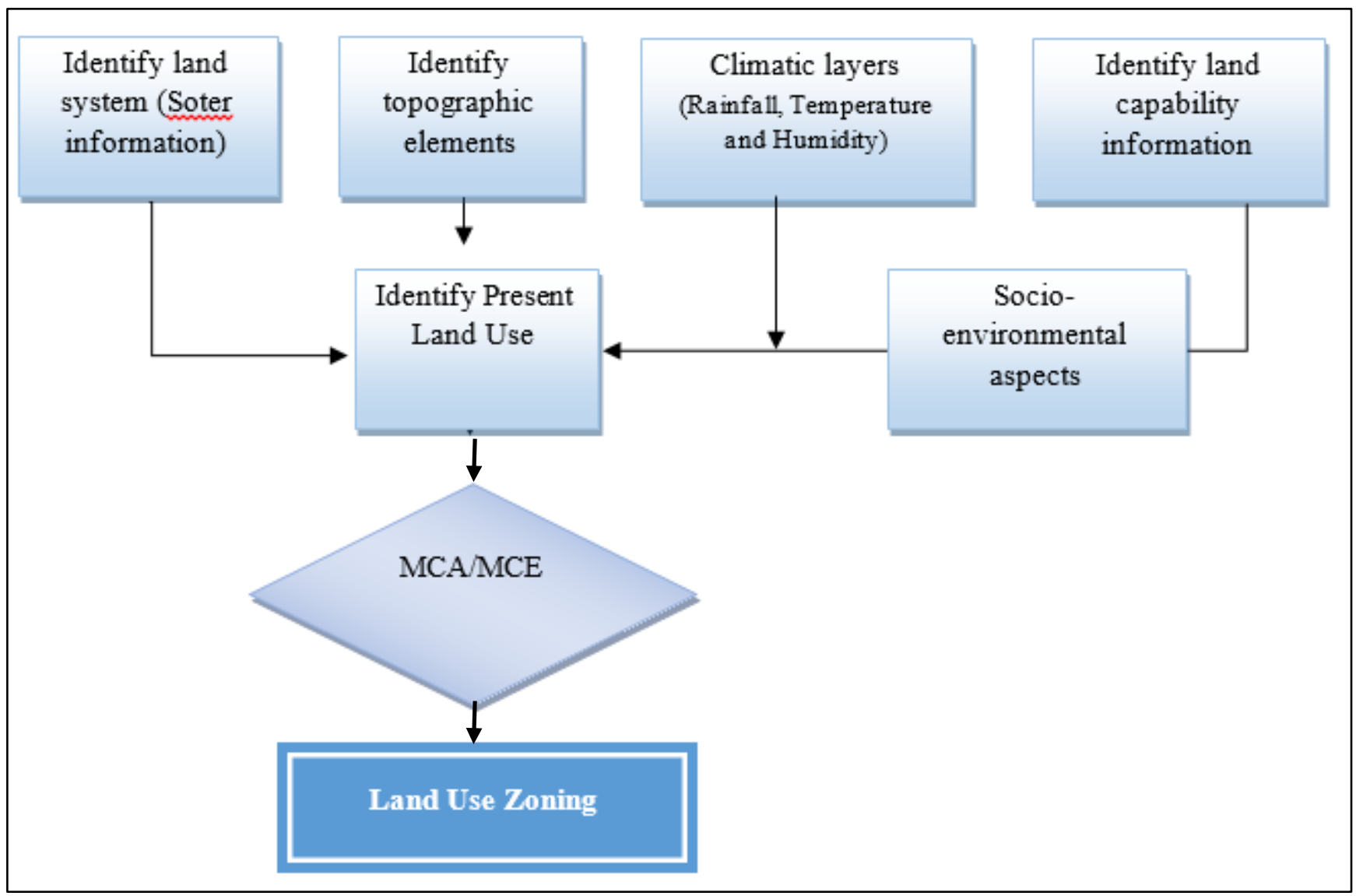

Fig. 2: Workflow for land use zoning 
D. Chalise et al. (2016) Int J Appl Sci Biotechnol, Vol 4(4): 458-463

Table 1: Hierarchies of land use zones and sub zones

\begin{tabular}{|c|c|c|c|c|}
\hline Zone No. & Zone Type & Sub type & $\begin{array}{l}\text { Data } \\
\text { Type }\end{array}$ & Description \\
\hline \multirow{6}{*}{ Zone 1} & \multirow{6}{*}{$\begin{array}{l}\text { Agricultural } \\
\text { Zone }\end{array}$} & Zone $1 \mathrm{~A}$ & String & Cereal crop production area \\
\hline & & Zone 1B & String & Cash crop area \\
\hline & & Zone 1C & String & Horticultural area \\
\hline & & Zone 1D & String & Animal husbandry area \\
\hline & & Zone 1E & String & Fish farming area \\
\hline & & Zone $1 \mathrm{~F}$ & String & Agro forestry area \\
\hline \multirow{2}{*}{ Zone 2} & \multirow{2}{*}{$\begin{array}{l}\text { Residential } \\
\text { Zone }\end{array}$} & Zone $2 \mathrm{~A}$ & String & Existing residential zone \\
\hline & & Zone 2B & String & Potential area for residential zone \\
\hline \multirow{2}{*}{ Zone 3} & \multirow{2}{*}{$\begin{array}{l}\text { Commercial } \\
\text { Zone }\end{array}$} & Zone $3 \mathrm{~A}$ & String & Governmental institutions and service areas \\
\hline & & Zone 3B & String & Business area \\
\hline \multirow{2}{*}{ Zone 4} & \multirow{2}{*}{$\begin{array}{l}\text { Industrial } \\
\text { Zone }\end{array}$} & Zone 4A & String & Areas under industrial use \\
\hline & & Zone 4B & String & Potential areas for industrial use \\
\hline \multirow{2}{*}{ Zone 5} & \multirow{2}{*}{ Forest Zone } & Zone $5 \mathrm{~A}$ & String & Existing forest \\
\hline & & Zone 5B & String & Potential area for forest including barren lands, wet lands etc. \\
\hline \multirow{6}{*}{ Zone 6} & \multirow{5}{*}{$\begin{array}{l}\text { Public Use } \\
\text { Zone }\end{array}$} & Zone 6A & String & Areas under roads, railways, bus parks, airport and land fill site etc. \\
\hline & & Zone 6B & String & $\begin{array}{l}\text { Areas under River/stream, canals, water sources, ponds, } \\
\text { sand/gravel etc. }\end{array}$ \\
\hline & & Zone 6C & String & Open spaces, picnic spots, playing grounds and stadiums etc. \\
\hline & & Zone 6D & String & Cultural/archeological and religious areas etc. \\
\hline & & Zone $6 \mathrm{E}$ & String & $\begin{array}{l}\text { Public health/education/library, police station, fire station, } \\
\text { telephone /electricity areas etc. }\end{array}$ \\
\hline & & Zone $6 \mathrm{~F}$ & String & Grazing land \\
\hline
\end{tabular}

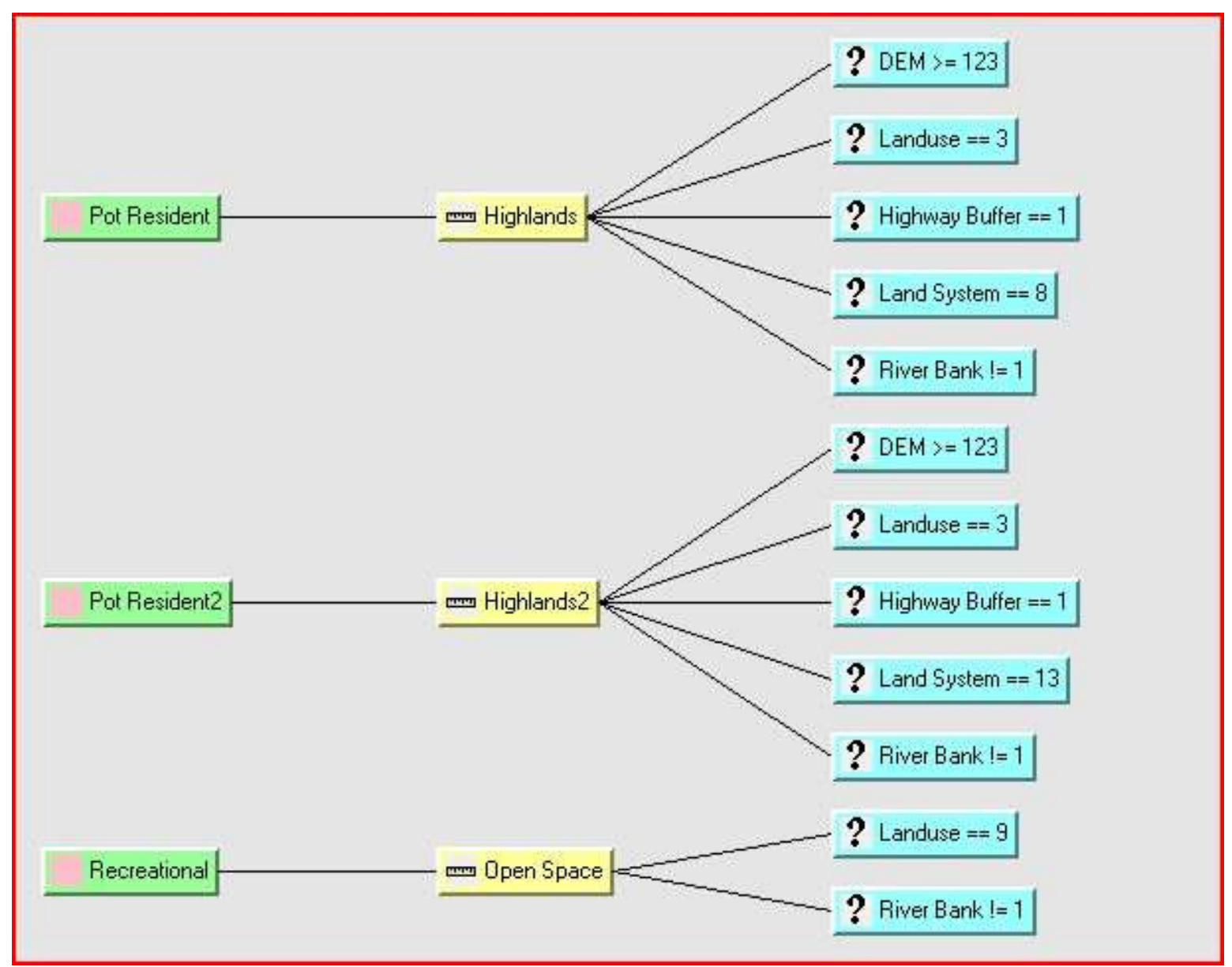

Fig. 3: Criteria for delineating residential and recreational zones 


\section{Suitability Rating Using Multi-Criteria Analysis}

Suitability ratings for six land use zones was developed using multi-criteria analysis in a GIS environment. Suitability ratings were based on land capability, present land use, socio-economic and demographic characteristics, accessibility to infrastructure and services. As said earlier, land capability maps was also developed using GIS based MCA analysis, which incorporate soil parameters, fertility, erosion susceptibility, terrain constraints and surface drainage (wetness).

The potential residential and recreational area has been delineated using the criteria shown in Fig. 3. The thematic layers considered were the elevation (>123 m), landuse (presently agriculture land), distance from highway (within $1 \mathrm{~km}$ ), land system (hilly/elevated area), distance from river (more than $100 \mathrm{~m}$ ).

\section{Results and Discussion}

\section{Land Use Zones}

Table 2 shows area coverage of different land use zone subtypes. Land use zoning is a pre-requisite for sustainable utilization of land resources by their allocation considering optimal production function. Land use zoning of the VDCs following National Land Use Policy of Government of Nepal and specifications provided by NLUP has shown that maximum area in this VDC is under forest zone $(66.62 \%)$ followed by agriculture zone $(20.83 \%)$. Area allocated as residential is $2.91 \%$, for commercial is $0.15 \%$, and for public use is $9.48 \%$. (Fig. 4).

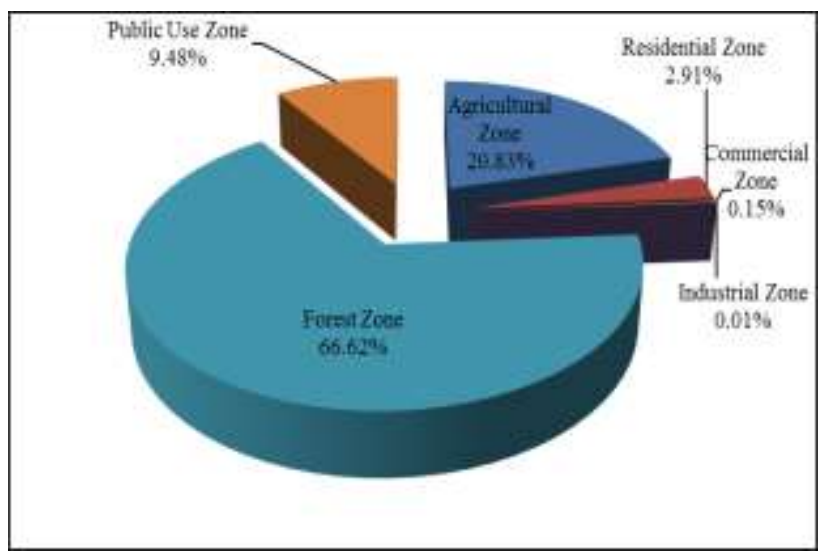

Fig. 4: Area under various Land Use Zones

Table 2: Area coverage of different land use zone sub-types

\begin{tabular}{|c|c|c|}
\hline Zone Type/Sub type & Area (ha) & Percentage \\
\hline Agricultural Zone & 2783.15 & 20.83 \\
\hline Zone 1A (Cereal crop production area) & 2192.27 & 16.41 \\
\hline Zone 1B (Cash crop area) & 590.88 & 4.42 \\
\hline Residential Zone & 388.37 & 2.91 \\
\hline Zone 2A (Existing residential zone) & 274.42 & 2.05 \\
\hline Zone 2B (Potential area for residential zone) & 113.95 & 0.85 \\
\hline Commercial Zone & 19.97 & 0.15 \\
\hline Zone 3A (Governmental institutions and service areas) & 8.13 & 0.06 \\
\hline Zone 3B (Business area) & 11.84 & 0.09 \\
\hline Industrial Zone & 1.98 & 0.01 \\
\hline Zone 4A (Areas under industrial use ) & 1.98 & 0.01 \\
\hline Forest Zone & 8901.83 & 66.62 \\
\hline Zone 5A (Existing forest) & 8854.13 & 66.27 \\
\hline Zone 5B (Potential area for forest including barren lands, wet lands) & 47.69 & 0.06 \\
\hline Public Use Zone & 1266.11 & 9.48 \\
\hline Zone 6A (Areas under roads, railways, bus parks, airport and land fill site etc.) & 157.58 & 1.18 \\
\hline Zone 6B (Areas under River/stream, canals, water sources, ponds, sand/gravel etc.) & 1004.80 & 7.52 \\
\hline Zone 6D (Cultural/archeological and religious areas etc.) & 0.03 & 0.0002 \\
\hline $\begin{array}{l}\text { Zone 6E (Public health/education/library, police station, fire station, telephone } \\
\text { /electricity areas etc.) }\end{array}$ & 53.53 & 0.40 \\
\hline Zone 6F (Grazing land) & 50.17 & 0.38 \\
\hline Total & 13361.40 & 100.00 \\
\hline
\end{tabular}




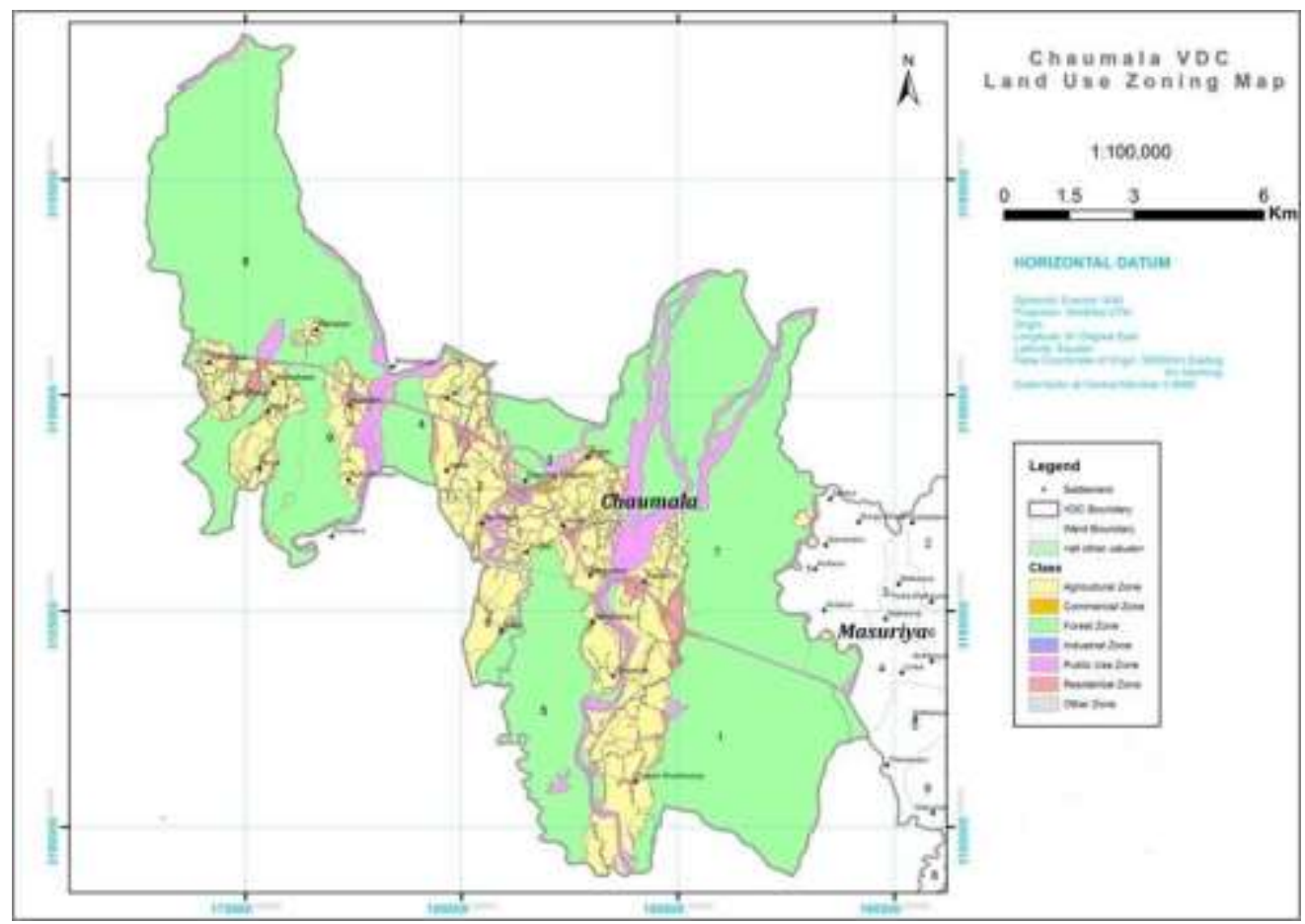

Fig. 5: Land use zoning map of study VDC

The land use zone maps of the VDC has been prepared using various data layers and setting appropriate and established criteria that best suits the region (Fig. 5). These data layers are primarily the soil types, topography and drainage, and moisture regime incorporated in the land capability classes, and the socio-economic and cultural features such as population, road access, distance from river and proximity or contiguity to existing urban or semi-urban settlements. In proposed land use zones, areas under exiting bush or shrubs and flood prone areas has been proposed for the forestry development, and the new areas for residential, commercial and industrial and public utility zone has been proposed on the existing agricultural land which lie adjacent to existing major settlement on main roads and highway, road crossings or those at the fringe of urban residential built-up areas.

\section{Acknowledgement}

Our sincere thanks go to government officials of National Land Use Project/Ministry of Land Reform and Management providing opportunity for working in the project.

\section{References}

Alexander ER (1998) Doing the 'Impossible': Notes for a General Theory of Planning. Environ. Plan. B: Plan. Design 25: 667-680. DOI: 10.1068/b250667
Anderson JR (1971) Land Use Classification Schemes used in Selected Recent Geographic Applications of Remote Sensing. Photogramm. Eng. 37(4): 379-387.

Blunden WR (1971) The Land-Use/Transport System: Analysis and Synthesis. Pergamon press, New York.

Catanese AJ (1972) Scientific Methods of Urban Analysis, University of Illinois Press, Chicago.

Chapin Jr. FS and Kaiser EJ (1979) Urban Land use Planning, 2nd Edition. University of Illinois Press, Chicago.

FAO (1993) Guidelines for Land Use Planning. Food and Agriculture Organization of the United Nations. Italy.

Government of Nepal (2012) National Land Use Policy, 2069.

Keeble L (1969) Principles and Practice of Town and County Planning, 4th Edition. The Estates Gazette Limited, London.

Last DG (1995) Incremental Land-Use Decision Making Displayed by County Zoning Committees. J. Soil Water Conserv. 50 (1): 21-24.

Sol VM, Lammers PEM, Aiking H, de Boer J and Feenstra JF (1995) Integrated Environmental Index for Application in Land Use Zoning. Environ. Manage. 19(3): 457-467. DOI: 10.1007/BF02471986

Van der Vlist MJ (1998) Land Use Planning in the Netherlands Finding a Balance between Rural Development and Protection of the Environment. Landsc. Urban Plan. 41: 135-144. DOI: 10.1016/S0169-2046(97)00068-6 